\title{
Peru as a New Major Actor in Latin American Coffee Production
}

\author{
by Jean-Christian Tulet ${ }^{1}$
}

Translated by Carlos Pérez ${ }^{2}$

\begin{abstract}
Despite the sustained effects of catastrophic economic policies, a terrible civil war, and a major decline in international prices, coffee production in Peru has increased phenomenally during the past decade and is now the nation's primary agricultural export. The increase makes Peru unusual among coffee-producing countries, and it can be explained in large part in terms of the response of small coffee growers to the disruption of traditional marketing networks. The experience of a small cooperative in the Department of Junín reveals that the alternative networks developed with the assistance of international nongovernmental organizations have not only provided coffee growers guaranteed prices that are higher than the international average and strengthened their position in the market but also facilitated improvements to the productive system and better management of natural resources.
\end{abstract}

Keywords: Peru, Coffee, Campesinos, Alternative trade networks, Environmental management

Peruvian coffee production has recently demonstrated extreme dynamism, with an increase in production from 96,700 tons in 1995 to 155,000 tons in 2005 and an increase in cultivated area from about 163,000 to 215,000 hectares in the same period (FAO, 2005). ${ }^{1}$ The country now ranks among Latin America's major coffee growers, with production equaling that of Honduras, which has also seen robust growth, and greater than that of Costa Rica. If this trend continues, it is entirely possible to imagine that Peru will become the third-largest producer in that part of the world, although it is still far from the two major coffee growers, Brazil and Colombia.

This development is the more surprising when one takes into consideration that it occurred during a period of severe crisis accompanied by a major decline in production in numerous countries, including some of the most important ones (Mexico, 17 percent; El Salvador, 47 percent; Costa Rica, 18 percent; Ecuador, 55 percent). Among the major producing nations, only Brazil has escaped this slump, in fact registering the highest rate of growth during this period. In contrast to that in other countries, coffee production in Brazil is a speculative activity and is therefore characterized by booms and busts, one of which has occurred since 2006. This is not the case with Peru, where the expansion has experienced fewer shocks despite a steep decline in international coffee prices between 1997 (US\$134 per sack) and 2004 (US\$62 per sack), the darkest period in the history of coffee production (Table 1).

In Peru as in the most other coffee-growing countries, production increases as a result of the expansion of the area under cultivation (Table 2). (In Brazil,

\footnotetext{
${ }^{1}$ Jean-Christian Tulet is a geographer and director of research at the Laboratoire GEODE (Géographie de l'Environnement), Toulouse, France.

${ }^{2}$ Carlos Pérez is an associate professor and chair of the Department of Chicano and Latin American Studies at California State University, Fresno.
} 
in contrast, it has increased because of an increase in yields while the area planted in coffee has decreased.) This increase has occurred through growth in the numbers of small and medium-sized farms (less than 5 hectares), which represent 84 percent of the total. The majority of Peru's coffee-growing areas are located on the eastern slopes of the Andes, primarily in Cajamarca, Junín, Cuzco, and San Martín.

The development of coffee growing in the region known as the "Selva Central" began before World War II with the purchase of 500,000 hectares by a British company, the Peruvian Corporation, which concentrated on coffee growing. The demand for labor associated with this production led to a significant influx of wage workers from the highlands as well as from outside the country. These immigrants subsequently sought to establish themselves independently, which was relatively easy because land was abundant. The period after the war saw an intensification of the migratory flow into the "Andean piedmont," and immigrants took advantage of the departure of the British company to purchase the land it had abandoned. After the 1960s, government efforts to improve communications allowed better integration of the region into the rest of the country.

TABLE 1

Development of Coffee Production in Latin America, 1996-2004

\begin{tabular}{lrrr}
\hline Country & 1996 (tons) & 2004 (tons) & Percentage Change \\
\hline Brazil & $1,369,196$ & $2,466,860$ & +80.0 \\
Peru & 106,052 & 185,000 & +74.0 \\
Honduras & 143,830 & 185,000 & +24.0 \\
Dominican Republic & 41,641 & 51,000 & +22.0 \\
Colombia & 671,401 & 680,580 & +1.4 \\
Venezuela & 73,026 & 71,503 & -2.0 \\
Guatemala & 240,300 & 216,600 & -10.0 \\
Mexico & 374,153 & 310,861 & -17.0 \\
Panama & 10,478 & 8,700 & -17.0 \\
Costa Rica & 154,131 & 126,000 & -18.0 \\
Puerto Rico & 12,175 & 10,000 & -18.0 \\
Cuba & 16,680 & 12,900 & -23.0 \\
El Salvador & 148,859 & 78,522 & -47.0 \\
Ecuador & 190,695 & 86,522 & -55.0 \\
\hline
\end{tabular}

Sources: Ministerio de Agricultura (2005), FAO (2005).

TABLE 2

Development of Coffee Production in Peru, 1980-2005

\begin{tabular}{lccc}
\hline & Cultivated Area (ha) & Yield (H.g./ha) & Product (tons of green coffee) \\
\hline $1979-1980$ & 153,730 & 6,230 & 95,830 \\
$1984-1985$ & 159,000 & 5,400 & 87,046 \\
$1989-1990$ & 163,311 & 5,250 & 93,747 \\
$1994-1995$ & 163,800 & 5,740 & 94,018 \\
$1999-2000$ & 220,265 & 6,880 & 151,577 \\
$2004-2005$ & 235,600 & 7,215 & 170,000 \\
\hline
\end{tabular}

Source: FAO (2005). 


\section{THE DISRUPTION OF TRADITIONAL TRADE NETWORKS}

Disastrous economic decisions eventually stalled this expansion. After some initial success, the agrarian reform promoted by the military government of Juan Velasco had catastrophic effects, especially after 1975, reinforcing the authoritarianism associated with a readjustment within the military. The actions of the subsequent governments aggravated an already difficult situation when they had to confront the unfavorable circumstances created by the drop in the price of primary export commodities, an increase in the interest on the external debt, and a decline of production due to climatic conditions. Nevertheless, between 1970 and 1980 the state supported cooperatives, primarily through the loans granted by the Agrarian Bank at favorable interest rates. Within the framework of the International Coffee Agreement (Díaz, 2006), it also funneled the profits from export quotas to the coffee cooperatives, which exported 80 percent of the country's production in the 1970s. Instead of encouraging improvement of the trading system, however, these privileges had the opposite effect. The cooperatives, with sales guaranteed, made no effort to improve their operations. The majority continued to be small and were often characterized by inflexibility, nepotism, and corruption. These adverse conditions aggravated the disorganization of the coffee commodity chain after 1989, when the abandonment of the International Coffee Agreement deprived the cooperatives of the advantages of the quota system. Subsequently, mismanagement made them even more vulnerable.

This vulnerability increased with the structural adjustment policies of the Alberto Fujimori administration as the state retreated from intervention in the production and trade networks. While it continued to provide material aid to the poorest peasants, it dissolved the Agrarian Bank and put an end to agricultural price supports in the name of the free play of market forces. Its retreat led to the proliferation of private intermediaries and exporters that were often incapable of assuming its responsibilities, increasing the disorganization of the market's distribution system.

Obviously, terrorism, for which the economic crisis provided fertile ground, aggravated the situation. The coffee-growing zones were especially hard-hit by this subversion, notably in the Department of Junín. After the 1980s, insecurity contributed in large measure to the decline of institutional operations. Along with the violence unleashed by Shining Path guerrillas, there were repressive government measures involving the same methodsforced recruitment, the destruction of harvests or plantations, and summary executions. The rural population, trapped in the crosshairs, had no option but to flee and seek refuge in the cities. This contributed to a decline in agricultural production and the disruption of existing trade networks. Support services in the countryside deteriorated and credit disappeared, along with the majority of the coffee growers' organizations, which exported only a minuscule part of their total production. 
The accumulation of all of these adverse factors resulted in a decrease in investment by coffee growers in capital and labor, including a reduction in currency inflows, the loss of markets, and a deterioration of coffee quality. In some cases the flight (not always temporary) of part of the rural population caught in the combat zone affected investment over time, and the government did very little to correct the situation. Recently, the National Coffee Board denounced governmental indifference and the "invisibility" of coffee issues in public policy: "For [Alejandro] Toledo's government, Peru neither produces nor exports coffee" (Junta Nacional del Café, 2006). At the same time, the weakening of the traditional state institutions contributed to the emergence of a new type of private actor, the nongovernmental organization (NGO) for rural development and international technical cooperation, and numerous "alternative" institutions were developed in an attempt to fill the void (see Díaz, 2006: 137-145, for a review and critique of these efforts).

\section{THE IMPORTANCE OF ALTERNATIVE NETWORKS}

The disruption of the traditional networks created an opportunity for the development of alternative networks that now occupy a significant place in the country. In 2006 the market for specialty coffees constituted 14 percent of the total volume of Peruvian exports - a far larger proportion than is usually found in coffee-growing countries. Fair Trade represents only 0.01 percent of international trade, but its importance is increasing. According to the Fairtrade Labelling Organization (FLO, 2003), sales have increased internationally from 11,663 tons in 1998 to 19,895 tons in 2003.

Exports of Peruvian specialty coffee exports, begun in 1997, have steadily increased. While in 2002 they were less than 10 percent of total exports (although they represented 14 percent in value), in 2004 they amounted to 14 percent (Ugaz, 2005). This expansion has increased since the political violence subsided, but the traditional local and international commercial houses have remained doubtful about investment. By the end of the 1990s some cooperatives had achieved some access to solidarity markets. The Peruvian specialty coffee market has the following components (Junta Nacional de Café, cited by Deneu-Casanova, 2005):

1. "Biological" coffee, locally known as organic coffee (71 percent), which benefits from costly certification by international organizations that guarantee both the total absence of any chemical inputs in the coffee groves and in the process of transforming the coffee berry into commercial green coffee.

2. Fair Trade coffee (14 percent), which offers small coffee growers prices higher than the world average and guarantees relatively price stability and rapid payment, including a prefinancing option that helps coffee growers avoid underselling or taking on usurious loans. The fair price covers the costs of production (including the environmental and social ones), assuring the coffee growers a dignified life and the possibility of investment.

3. "Sustainable" coffee (11 percent), the coffee growers of which must fulfill various requirements for the protection of the environment, guarantee better working 
conditions for workers, and avoid abuses such as child labor. The coffee price is not always fixed contractually.

4. Gourmet coffee (4 percent), which is defined by the quality of the product in the cup and commands prices very much higher than the world-market average.

In Peru, there are numerous institutions involved in Fair Trade. For example, the CAC Palomar cooperative has more than 1,500 members and exports more than 3,000 tons of coffee, 27 percent of it under the Fair Trade label, and the COCLA cooperative has 8,000 members and sells close to 12,000 tons of coffee. The example presented here, the Cooperativa de Frutos Ecológicos Sanchirio El Palomar, is much more modest.

\section{THE COOPERATIVA DE FRUTOS ECOLÓGICOS SANCHIRIO EL PALOMAR}

Located in the central piedmont of the Peruvian Andes at an elevation of 1,400-1,900 meters, the municipality of El Palomar, in the Department of Junín, is primarily composed of little-exploited tropical rain forest. This steep slope from the Peruvian Andes into the Amazon jungle is crisscrossed by a series of valleys that offer many opportunities for settlement at intermediate altitudes, which not only lack the various diseases (such as malaria) endemic to the tropics but also are conducive to coffee production. Whereas only 16 percent of Peru's agricultural land is suitable for permanent farming, the figure for Junín is 25 percent (Gran Atlas del Perú, 2005), and the department is responsible for 20 percent of the country's coffee production.

The colonization of the area began in the 1930s, when a group of settlers received land from the state that had been purchased from the Peruvian Corporation. This initial nucleus gradually increased. In 1946 there were 118 settlers, and the town of Sanchirio was founded in August 1954. ${ }^{2}$ Interest in the exploitation of these new lands has long contributed to an influx of settlers from the highlands. Sanchirio, the municipal seat of El Palomar, has about 800 families, of which 600 are dispersed in 12 villages. Access to the region is difficult; it is 12 hours by road from the closest service center, La Merced.

During the period of the guerrilla war, between 1985 and 1997, guerrillas of the Shining Path and the Tupac Amaru Revolutionary Movement occupied or roamed throughout the region of El Palomar, trying to control the peasantry in any way possible. The population also suffered from the operations initiated by the regular military. In this violent context, which threatened their very survival, nearly 70 percent of the population emigrated to the urbancenters of La Merced, Tarma, and Lima. This exodus led to the abandonment of much of the coffee-producing area for more than a decade, producing a decline in agricultural production, the desertion of plots, and an increase in plant diseases. When the farmers returned after 1997, it was to a devastated environment, and they had to reconstruct everything from scratch. A group of coffee growers united to form a cooperative called the Empresa Comunal de Servicios Agrícolas El Palomar (Arché, 2003). 
The organization began with a membership of 50 , and their association allowed them to hire the services of an agronomist. Despite numerous efforts, this attempt did not survive the loss of the state program of technical and commercial assistance. Subsequently, in 2001, a new, much smaller communal enterprise (differing in juridical status from a cooperative) called Sanchirio Organic Coffee was initiated with the support of the NGO Solidarite avec l'Amérique Latine pour le Développement Autonome des Communautés (SALDAC). One of the objectives of SALDAC is to support this association on the margins of the coffee commodity chain by promoting exports to France under advantageous conditions that would permit the farmers to cover their basic necessities and contribute to their economic development. SALDAC's activities are similar to those of Fair Trade, with a charter and a code of conduct, but involvement in them is based on self-identification and voluntary commitment rather than on certification obtained from a third party. The focus is on improving the quality of the coffee produced and obtaining its certification as organic. SALDAC's operations began during the harvest of 2001 and involved 7 tons of green coffee (around 10 percent of local production).

SALDAC's role is much more than that of importer. It administers the stages of roasting and marketing of the final product and supports the development of the cooperative. By fulfilling the directives on the production process and respecting the environment, it offers a fixed purchase price higher than that available on the world market, guarantees the continuation of the relationship, and grants funding. The cooperative's internal development fund, created by withholding a portion of the price of every sack of exported coffee, permits social investment in the community and the improvement of productive technology. In 2003 the cooperative acquired land to build a processing plant, which not only allowed it to manage the logistics of the harvest but also helped to improve the quality of the product and provided the infrastructure for wet processing. In 2005 it constructed a granary for the drying and storage of parchment coffee. ${ }^{3}$ In 2006 it laid a cement slab for drying and bought a dryer (which does not yet work because of the lack of a local electrical grid). All of these initiatives were undertaken in response to problems associated with the drying process, which was extremely difficult because of the humid environment. The purchase of this equipment was accompanied by a restructuring and rehabilitation of the coffee plantations.

This communal enterprise became a cooperative in 2004 with the objective of improving the promotion of its products among international buyers and taking advantage of an exemption from taxation. The cooperative, with 80 founding members, was named the Cooperativa de Frutos Ecológicos Sanchirio El Palomar and supported by CARITAS-Peru, a Catholic organization, and the USAID's antipoverty Proyecto PRA. Its objectives were the marketing of coffee and the technical improvement of the production system and its internal organization, with special attention to the incorporation of women. The cooperative seeks to improve the living conditions of the local population with regard to nutrition and health, develops programs for reforestation and natural-resources management, and is considering a new certification that would involve better coffee prices and better control of wastewater and the establishment of plant buffers bordering rivers and streams and next to roads. 
There are always difficulties. SALDAC cannot accept all of the production of the cooperative's members, and therefore the cooperative is working with the Finnish importer ANDESA and La Florida, another, much larger local cooperative. The marketing networks continue to be problematic. Furthermore, the cooperative always has insufficient means, especially in the area of personnel and equipment, although it has recently acquired a computer for accounting and administrative purposes. What is lacking, however, is an efficient communication network; telephones are still rare.

\section{THE EFFECTS OF FAIR TRADE AT THE LOCAL LEVEL}

\section{THE ADVANTAGES}

One of the most attractive advantages of the association between cooperative members and SALDAC is the return to the grower, which amounts to 20 percent of the price the consumer pays as opposed to the usual 7 percent. ${ }^{4}$ The price differential is especially appealing during periods of crisis but much less so during a recovery such as is going on today. Some coffee growers therefore consider the price differential insufficient to justify the carerequired by quality production.

SALDAC not only guarantees the price and the marketing of the quantities previously contracted but also funds part of the harvest. The cooperative can therefore supply organic fertilizers to its members (to be paid for when the harvest is sold) and lend small sums (without interest) to cover some of the costs. These factors certainly contribute to the appeal of this system for coffee growers, but it has other advantages as well:

1. Improvement of the productive system: coffee growers can now use their processing plant to convert their coffee berries into parchment coffee. Their new equipment is well-suited to the required agroecological conditions (which is not always the case with the plants belonging to individual coffee growers), and the coffee is better-threshed and better-dried.

2. A stronger position in the market.

3. Better management of natural resources and, consequently, access to the specialty-coffee market.

4. Increased consideration of women's role, which continues to be almost invisible in coffee production except for the harvest. In February 2006 a women's committee was created within the cooperative for the production and marketing of pineapple marmalade.

5. Financing, using the amount withheld from the price of every sack of coffee exported, not only of purchases of equipment but also of works of general interest such as roads and access to the electrical grid. 


\section{FRAGILE AND UNEVEN IMPROVEMENTS}

This marketing model seems to be perceived as advantageous for the community of coffee growers as a whole, and this has led to a real attachment on the part of some members to the cooperative and its contractual procedures. This attachment is not, however, universal. The leaders of the cooperative deplored the weak participation in a recent general assembly, and the SALDAC representative expressed surprise that certain coffee growers, though benefiting from advances, had still not delivered the coffee promised even though the harvest was long past.

Moreover, the improvements in the productive system are very uneven. The coffee produced is certainly excellent because of the extreme care taken in harvesting, husking, and drying. The beans are carefully selected, and the final product demonstrates very few defects. Undoubtedly, the general quality of at least the coffee destined for alternative markets is a result of the recommendations and controls implemented, but these improvements primarily affect the final stage, after the harvest. In contrast, the work on the land is very much neglected, with little of the weeding, application of nutrients, and provision of shade necessary with the extremely productive new varieties (primarily caturra and catimor, supplementing the traditional typica and bourbon). Plant density per hectare is mediocre (about 3,000), and yields are very modest (about 15 45-kg sacks per hectare when these varieties are producing some 50-100 sacks in other areas). This means a very significant reduction of profits. There is also very little productive diversification and a weakness in personal consumption. Except in cases of intensive coffee growing, with a density of up to 10,000 plants per hectare (which excludes other plants), peasant coffee growing is usually relatively diversified, with numerous other fruit trees (avocados, oranges, guavas), Musaceae, tubers (especially yucca), and sugarcane contributing a significant part of the family diet (which otherwise is relatively well-balanced) both directly and indirectly (through poultry). This is one of the reasons for the survival of coffee growers during economic crises. In Sanchirio there are numerous types of Musaceae, as well as some avocados and poultry (along with guinea pigs), but not much more. Pigs are entirely absent, although it would be very easy to feed them with the surplus from their plots. In the coffee-growing regions of Colombia, this absence would be unthinkable.

There are probably various explanations for this deficiency, among them, for example, a disease that affected papaya trees. It may be significant that these populations, often coming from the highlands, have adopted coffee growing without a previous model and have had to learn or invent everything, sometimes at a high cost. (For example, one immigrant family was ruined because it planted coffee at a very high elevation and coffee in Latin America cannot tolerate altitudes above 1,500-1,600 meters.) At the same time, it is possible that their lack of initial experience has made them more receptive to recommended innovations such as the requirements established for organic and Fair Trade coffees. 


\section{CONCLUSION}

The development of Peruvian coffee production has many paradoxes. While having one of the strongest growth rates in Latin America, it has developed in a context deeply influenced by the crisis that the country was undergoing and the disruption of trade networks. The emergence of alternative networks supported by international organizations occurred primarily because of the loss of the traditional ones. When they could, coffee growers joined the Fair Trade network, which helped to improve the quality of the product and their access to the market, but this was a fragile situation. The recommendations were not always perceived as logical or necessary, especially when they required additional effort, and were generally considered an inconvenience. The Cooperativa de Frutos Ecológicos Sanchirio El Palomar has survived largely because of the efforts of a small group of members; if they had done less there would have been serious management problems. Furthermore, involvement in the network has generated internal disparities that called into question the collective project, and the importance of the commitment of the SALDAC representative, which was largely determined by that individual's level of political activism, is another weak point. Participation in the new networks has, however, improved the living conditions of those involved and created a new awareness of environmental problems and a pursuit of solutions to them. Finally, all this has been accomplished by a segment of the population that has generally continued to live in poverty.

\section{NOTES}

1. Statistics on national coffee production vary with the source. For example, the Ministry of Agriculture gives the figure of 176,000 tons for 2005.

2. The name "Sanchirio" comes from the indigenous word ashanika (cold water); the valley receives the torrential rivers that flow from the highlands.

3. Parchment coffee is coffee from which the mucilage has been removed but that continues to be covered by a thin film (or parchment) that preserves it. Green coffee is coffee from which that film has been removed (an operation performed before sea transport).

4. According to an association brochure, the price of a $250 \mathrm{~g}$ package of SALDAC ground coffee is broken down as follows: 20 percent to the producers, 5.6 percent for international transport (including warehousing, logistics in France, and customs), 7 percent for packaging, 7.5 percent for roasting, 11.4 percent for distribution, 20 percent for SALDAC's other costs, and 28.5 percent profit for the retailer.

\section{REFERENCES}

Arché, Kolia

2003 "Transformations, mutations et restructuration de l'économie et de la société dans les Andes centrales du Pérou, de 1968 à 2000." Ph.D. diss., Université de Toulouse-Le Mirail. 


\section{Deneu-Casanova, Cecile}

2005 "La labellisation biologique: stratégies de développement paysan dans les Andes centrales péruviennes, le cas de la cooperativo café Sanchirio Palomar." Master's thesis, Département de Géographie, Université de Toulouse-Le Mirail.

Díaz Pedregal, Virginie 2006 Commerce equitable et organizations de producteurs: Le cas des caféicultures andins au Pérou, en Equateur et en Colombie. Paris: L'Harmattan.

FAO (Food and Agriculture Organization) 2005 http://www.fao.org.

FLO (Fairtrade Labelling Organization) 2003 http:/ / www.fairtrade.net.

Gran Atlas del Perú 2005 Diario La República. Lima.

Junta Nacional del Café 2006 Editorial. El Cafetalero, no. 19, February.

Ministerio de Agricultura, República del Perú 2005 http:// peru.gob.pe.

Ugaz Gomez, Jorge 2005 Del campo a la taza: Insumos tecnológicos para la producción de cafés de calidad. Lima: Proyecto Tambopata Inambari. 